\title{
UJI AKTIVITAS ANTIOKSIDAN SEDIAAN SIRUP DAUN SEREH (Cymbopogon citratus)
}

\author{
Dina Febrina ${ }^{1)}$, Desy Nawangsari ${ }^{2}$ \\ ${ }^{1), 2)}$ Program Studi Farmasi Sekolah Tinggi Ilmu Kesehatan Harapan Bangsa Purwokerto \\ 1)
}

\begin{abstract}
ABSTRAK
Antioksidan adalah senyawa yang dapat menghambat spesies oksigen reaktif dan juga radikal bebas sehingga antioksidan dapat mencegah penyakit yang terkait dengan radikal bebas seperti karsinogenesis, kardiovaskular, dan penuaan. Munculnya respons negatif terhadap penggunaan antioksidan sintetik diduga berpotensi menyebabkan kanker. Sehingga antioksidan alami semakin diminati karena diyakini lebih aman bagi kesehatan. Serai (Cymbopogon citratus) adalah salah satu tanaman yang biasa digunakan sebagai bumbu oleh masyarakat Indonesia. Penentuan aktivitas antioksidan sirup serai dilakukan dengan metode DPPH. hasilnya menunjukkan nilai IC50 dari persiapan sirup serai 50,68 ppm.
\end{abstract}

\begin{abstract}
Antioxidants are compounds that can inhibit reactive oxygen species and also free radicals so that antioxidants can prevent diseases associated with free radicals such as carcinogenesis, cardiovascular, and aging. The emergence of a negative response to the use of synthetic antioxidants is thought to have the potential to cause cancer. So that natural antioxidants are increasingly in demand because they are believed to be safer for health. Lemongrass (Cymbopogon citratus) is one of the plants commonly used as spices by the people of Indonesia. Determination of antioxidant activity of lemongrass syrup was carried out by DPPH method. the results showed an IC50 value of lemongrass syrup preparations of $50.68 \mathrm{ppm}$.
\end{abstract}

Viua Medika | EDISI KHUSUS/SERI 2/ FEBRUARI/2018 
Sereh (Cymbopogon citratus)

\section{PENDAHULUAN}

Antioksidan didefenisikan sebagai inhibitor yang bekerja menghambat oksidasi dengan cara bereaksi dengan radikal bebas reaktif yang membentuk radikal bebas tidak reaktif yang tidak stabil. Antioksidan merupakan semua bahan yang dapat menunda atau mencegah kerusakan akibat oksidasi pada molekul sasaran.

Antioksidan merupakan senyawa yang dapat menghambat spesies oksigen reaktif dan juga radikal bebas sehingga antioksidan dapat mencegah penyakit penyakit yang dihubungkan dengan radikal bebas seperti karsinogenesis, kardiovaskuler, dan penuaan (Siagian, 2002).

Munculnya respon negatif
penggunaan antioksidan sintetis diduga
berpotensi menyebabkan kanker. Sehingga
antioksidan alami semakin diminati karena
dipercaya lebih aman untuk kesehatan.

Menurut Warsi dan Gunarti (2013) dan Ayu et al. (2006) antioksidan alami seperti paprika dan daun kemangi berpotensi meredam kereatifan radikal bebas, juga dapat melindungi lipid dari kerusakan oksidatif. merupakan salah satu tanaman yang biasa digunakan sebagai rempah oleh masyarakat Indonesia. Sereh merupakan tumbuhan yang masuk ke dalam family rumputrumputan. Dikenal juga dengan nama sereh (Indonesia), dan sereh (Sunda). Tanaman ini dikenal dengan istilah Lemongrass karena memiliki bau yang kuat seperti lemon, sering ditemukan tumbuh alami di negara-negara tropis (Wijayakusumah, 2005). Komposisi minyak sereh ada yang terdiri dari beberapa komponen, yang isinya antara lain alkohol, hidrokarbon, ester, aldehid, keton, oxida, lactone, terpene dan sebagainya.

Tabel 1. Susunan kimia sereh

\begin{tabular}{lc}
\hline \multicolumn{1}{c}{ Senyawa Penyusun } & Kadar (\%) \\
\hline Sitronelal (antioksidan) & $32-45$ \\
Geraniol (antioksidan) & $12-18$ \\
Sitronellol & $12-15$ \\
Geraniol asetat & $3-8$ \\
Sitronellil asetat & $2-4$ \\
L-Limonene & $2-5$ \\
Elemol \& Seskwiterpene & $2-5$ \\
lain & $2-5$ \\
Elemene \& Cadinene & \\
Sumber : Guenther (2006) \\
\multicolumn{2}{c}{ Menurut Suprianto (2008) kadar air } \\
daun sereh yaitu 76,78\%, kadar abu 0,79\%, \\
\multicolumn{2}{l}{.2018 }
\end{tabular}


dan kadar minyak atsiri $0,25 \%$. Vitamin A berkisar 0,1 IU/100 g, vitamin B berkisar 0,8 $\mathrm{mg}$ dan vitamin $\mathrm{C}$ sekitar $4 \mathrm{mg}$. Juga menyediakan mineral penting seperti potasium, kalsium, magnesium, fosfor, mangan, tembaga, seng dan besi yang dibutuhkan untuk fungsi tubuh yang sehat. Sereh tidak mengandung kolesterol berbahaya atau lemak. Manfaat sereh terutama pada batang dan daun yang kering digunakan untuk bumbu masak, minyak wangi, bahan pencampur jamu, dan juga dibuat minyak atsiri. Kandungan kimia tanaman sereh lebih banyak terdapat pada batang dan daun.

Penggunaan sereh dengan dibuat sediaan sirup akan sangat memberi kepraktisan sebagai minuman dalam membantu kesehatan.

\section{METODE PENELITIAN}

Dilakukan penentuan kadar flavonoid total dengan menggunakan standar quercetin pada panjang gelombang $400-500 \mathrm{~nm}$.

Uji aktivitas antioksidan dilakukan dengan metode DPPH.

\section{HASIL DAN PEMBAHASAN}

Hasil penetapan kadar flavonoid total daun sereh ditunjukkan pada Tabel 1. berikut:

Tabel 1. Penetapan Kadar Flavonoid Total Ekstrak Etanol daun sereh (Cymbopogon citratus)

\begin{tabular}{cccc}
\hline & $\begin{array}{c}\text { Kandungan } \\
\text { flavonoid } \\
(\mathbf{m g} / \mathbf{L})\end{array}$ & $\begin{array}{c}\text { Rata-rata } \\
\text { kandungan } \\
\text { flavonoid } \\
\text { total (mg/L) }\end{array}$ & $\begin{array}{c}\text { Kadar } \\
\text { flavonoid } \\
\text { total (\%) }\end{array}$ \\
\hline 1 & 0,02810 & & \\
2 & 0,03120 & 0,02912 & 2,912 \\
3 & 0,02806 & & \\
\hline
\end{tabular}

Sirup formula I (sukrosa : Na CMC $(0,75: 0,25))$ merupakan formula terpilih, karena memiliki rasa dan penampilan menarik, tingkat kekentalan yang rendah, endapan paling sedikit dan lebih layak diterima pasar selanjutnya dilakukan uji aktivitas antioksidan untuk memastikan aktivitas antioksidan ekstrak daun sereh tidak mengalami perubahan setelah diformulasikan. Uji aktivitas antioksidan dilakukan dengan metode DPPH yang merupakan metode yang sama dengan uji pendahuluan.

Sediaan sirup sereh akan dibandingkan dengan kontrol vitamin $\mathrm{C}$ yang juga dibuat sediaan sirup sesuai dengan formulasi sirup sereh. Hasil 
penetapan nilai $\mathrm{IC}_{50}$ keduanya ditampilkan

pada Gambar 3. berikut:

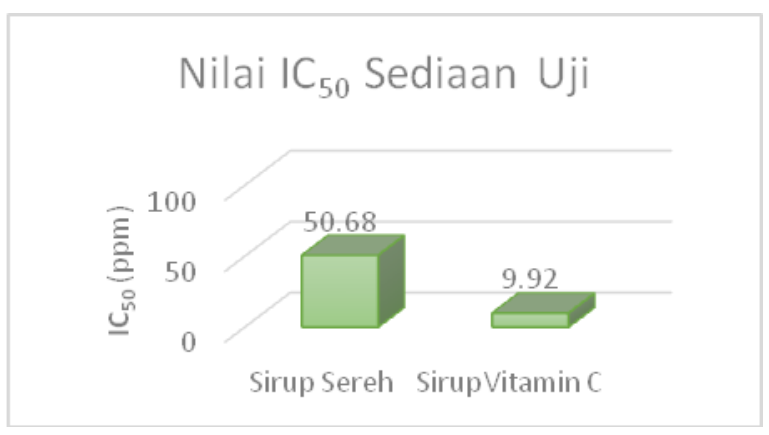

Gambar 1. Grafik Besarnya Nilai $\mathrm{IC}_{50}$ pada sediaan sirup daun sereh (Cymbopogon citratus) dan sirup vitamin $\mathrm{C}$

\section{KESIMPULAN}

Sereh memiliki potensi antioksidan yang baik dan dapat dibuat sebagai sediaan sirup sehingga dapat dikonsumsi secara mudah.

\section{DAFTAR PUSTAKA}

Arisman, 2009, Keracunan Makanan, EGC. Jakarta.mh

Ayu R, Manullang M, Comelia M. 2006. Pengaruh penambahan ekstrak daun kemangi (Ocimum basillicum L.) terhadap ketengikan minyak kelapa sawit. Jurnal Ilmu dan Teknologi Pangan. 4(2): 13-32.

Departemen Kesehatan RI, 1986, Sediaan Galenik, Jakarta : Departemen Kesehatan RI.
Ewansiha JU, Garba SA, Mawak JD, Oyewole OA. 2012. Antimicrobial Activity of Cymbopogon citratus (Lemon Grass) and It's Phytochemical Properties. Frontiers in Science. 2(6):214-220.

Ferreira IMPLVO, Pestana N, Alves MR, Mota FJM, Reu C, Cunha S,Oliveira MBPP. 2004. Quince jam quality: microbiological, physicochemical, and sensory evaluation. Food Control.15:291295.

Kusumayadi IWH, Sukewijaya IMS, Sumiartha IK, Antara NSA. 2013. Pengaruh ketinggian tempat, mulsa, dan jumlah bibit terhadap pertumbuhan dan rendemen minyak sereh dapur (Cymbopogon citratus). E-J Agro Trop. 2 (1): 2301-6516.

Marks DB, Marks AD, Smith CM. 2000. Biokimia Kedokteran Dasar: Sebuah Pendekatan Klinis. Brahm U, Pendit, penerjemah; Suyono J, Sadikin V, Mandera LI, editor. Jakarta(ID): Penerbit EGC. Terjemahan dari: Basic Medical Biochemistry: A Clinical Approach.

Mirghani MES, Liyana Y,Parveen J. 2012. Bioactivity analysis of lemongrass (Cymbopogan citratus) essential oil. Inter Food Res J. 19: 569-575 (2012).

Molyeux, P. 2004. The Use of Stable Free Radikal Diphenylpicrylhydrazyl (DPPH) for Estimating Antioxidant Activity. Journal of Science Technology 26(2):211-219 
Nadesul, H, 2006, Sehat Itu Murah, PT Kompas Media Nusantara. Jakarta.

Nambiar VS, Matela H. 2012. Potential function of lemon grass (Cymbopogon citratus) in health and disease. IJPBA; 3(5): 10351043.

Sirait. 2007. Penuntun Fitokimia Dalam Farmasi. Bandung : Penerbit ITB

Suryanto E, Katja DG, Wehantouw F. 2010. Singlet oxygen quenching activities of phenolic extract from lemon grass leaves (Cymbopogon citratus Stapf). Chem. Prog. 3(1): 612.

Tajidin NE, Ahmad SH, Rosenani AB, Azimah $\mathrm{H}$, Munirah $\mathrm{M}$. 2012.Chemical composition and citral content in lemongrass (Cymbopogon citratus) essential oil at three maturity stages. African $J$ of
Biotech.11:

2685-2693.doi:

10.5897/AJB11.2939.

Voight, R., 1994, Buku Pelajaran Teknologi Farmasi, Edisi V, Diterjemahkan Oleh Soendani Noerono, Yogyakarta : Universitas Gadjah Mada Press.

Warsi, Guntarti A. 2013. Aktivitas antioksidan ekstrak metanol buah paprika hijau (Capsicum annum L.). Jurnal Ilmiah Kefarmasian. 3(1): 919.

Winarno FG. 2008. Kimia Pangan dan Gizi.Jakarta: Gramedia Pustaka Utama.

Winarsi H. 2007. Antioksidan Alami dan Radikal Bebas. Yogyakarta (ID): Penerbit Kanisius. 